\title{
Japanese plans for international seismometer network shape up
}

Tokyo

JAPANESE seismologists are hopeful that plans to establish an international network of highly sensitive seimometers in the western Pacific and east and southeast Asia may soon begin to take shape. Although it will probably be the early 1990s before the long process needed to gain full government backing can be completed, there is confidence that the project will gain momentum much earlier.

The network, called POSEIDON (Pacific Orient Seismic Digital Observation Network), was described at an international symposium at Tokyo University earlier this month, and is intended to form part of an international global network being set up under the aegis of the Federation of Digital Broadband Seismic Networks (see Nature 328, 105; 1987).

The latest digital seismometers are capable of detecting ground motions over a tremendous range of frequencies and amplitudes, from tiny microearthquakes with periods of a fraction of a second up to Earth 'tides' caused by variations in the gravitational attraction of the Moon and Sun. Networks of these seismometers are being deployed around the world and will eventually enable geologists to ' $\mathrm{X}$-ray' the Earth from different angles and build up a detailed three-dimensional picture of the planet's internal structure.

The POSEIDON network will consist of about 50 stations in a grid extending from the Aleutian islands to Papua New Guinea, including about 20 on the floor of the western Pacific Ocean.

Until now these highly sensitive seismometers have been used only on land. Three options for sea-floor operation are being considered: temporary 'pop-up' systems that will float to the surface after a period of about six months on the seafloor; permanent seismometers linked to a surface buoy that will be equipped with an antenna for satellite transmission of data to a central processing centre; and a network directly linked to Japan by submarine optical fibre cable.

The cable option is the most appealing, but it is by far the most expensive $¥ 35,600$ million ( $\$ 260$ million) for 20 stations as opposed to a few thousand million yen each for the other two systems, according to estimates by $\mathrm{T}$. Kanazawa of Tokyo University.

Another approach being considered by Tokyo University's Earthquake Research Institute is to connect seismometers to an old trans-Pacific telephone cable, TPC-1, which will be abandoned next year and replaced with optical fibre cables. But there are objections from the US military, who currently use a section of the cable.
Regardless of which approach is adopted, Duncan Agnew of the University of California foresees problems in placing the seismometers on the sea floor. The seismometers are highly sensitive to tilt and much of the Pacific Ocean is floored with soft soupy mud. But Robert Geller, an associate professor at Tokyo University, is confident this problem can be overcome at sites with firm substrates. Another problem for these supersensitive instruments may be background noise, both on the sea floor and on land.

Japanese seismologists at the symposium went to great pains to emphasize on the one hand that POSEIDON has yet to receive government backing (apart from a few million yen for a feasibility study) and on the other to appeal to scientists in countries covered by POSEIDON to join the project.

There are ways in which seismometers can be deployed before POSEIDON is officially launched. Developing countries can apply to the Japan International Cooperation Agency for overseas aid to install seismometers and for training of their scientists. And Japanese seismologists can (and almost certainly will) apply to the Ministry of Education, Science and Culture by this November for grants of a few million yen to buy seismometers that can be installed overseas in fiscal year 1989. According to a member of one of the POSEIDON working groups, scientists from Indonesia, the Philippines and the Soviet Union have expressed interest in initiating the project by these sort of routes.

But a bureaucratic obstacle stands in the way: the Japanese government has no rules for the permanent installation of scientific equipment overseas (see Nature $311,5 ; 1984)$. But there is a way around the problem. The equipment can be 'temporarily' installed and then 'abandoned' under a bureaucratic procedure for dealing with obsolete equipment.

Harumi Aoki of Nagoya University, who is chairman of the Global Seismology subcommittee organizing POSEIDON, says it will probably take until the early 1990 s to win government funding for POSEIDON. But many organizations linked to various ministries are already backing the project. If the cooperation of other countries can be obtained the subcommittee will be in a much better position to apply to the government for support.

Robert Geller told foreign participants that they should not be discouraged if it takes five years to launch POSEIDON, because in Japan once a project gets going its very hard to stop. Once the flow of funds starts it will continue for many years.

\section{Space station surprise}

Prospects for the space station took an unexpected leap forward last week when the US Congress agreed to cut back on funds for the Environmental Protection Agency and disaster relief and increase support for the space station. The project will receive $\$ 900$ million in a new appropriations bill passed by both houses of Congress. The bill, which now goes to President Ronald Reagan for signing, provides any $\$ 250$ million less than NASA originally requested and $\$ 700$ million more than a Senate bill considered just last month.

A.A.

\section{Venereal disease spinoff}

THE West German Health Ministry last week reported a drastic reduction in the number of cases of sexually transmitted diseases. The incidence of gonorrhoea and syphilis in the first half of 1988 was one-quarter of that reported in the first half of 1985 . The ministry attributed the reduction to the AIDS information campaign. The number of newly registered infections with human immunodeficiency virus (HIV), the virus that causes AIDS, has also stopped increasing in West Germany. Until now, 20,956 HIV-positive people have been registered, among them 2,939 women.

S.D.

\section{Shuttle success at last}

AFter delays due to a leaky fuel line and a sticky valve, the main engines of the US space shuttle Discovery were successfully fired for 22 seconds on 10 August. The test caused great rejoicing within NASA, which has had little to cheer about lately, but before Discovery can be launched there remains one final test of the main booster rockets, presently scheduled for today, 18 August, in Utah, and the leaking fuel line must still be fixed. NASA officials now believe they can make the repair without rolling Discovery back off the launching pad, and are talking of a launch in late September, although no date has officially been set.

D.L.

\section{Forward march}

THE space programme of the People's Republic of China received a boost on 5 August with the launch of a Long March 2 rocket carrying West German microgravity experiments. The payload was to remain in space for eight days and return to Earth by parachute in China. A set of 104 protein samples from West German pharmaceutical companies was to crystallize in space under near-weightless conditions. The companies will use the crystals to study the structure and function of the compounds once they return to Earth.

The DM1.2 million launch costs and 80 per cent of the DM1.5 million project costs were paid by the West German Research and Technology Ministry. The pharmaceutical companies paid the rest.

S.D. 